\title{
Investigation of PISA 2015 Reading Ability Achievement of Turkish Students in Terms of Student and School Level Variables
}

\author{
Kazim Celik (iD) 1,*, Ahmet Yurdakul(D) 2 \\ ${ }^{1}$ Department of Education, Faculty of Education, Pamukkale University, Denizli, Turkey \\ ${ }^{2}$ Directorate of National Education, Usak, Turkey
}

\section{ARTICLE HISTORY}

Received: 09 July 2019

Revised: 25 November 2019

Accepted: 26 January 2020

\section{KEYWORDS}

PISA,

Reading ability,

Hierarchical linear model,

Student level factors,

School level factors,

\begin{abstract}
The aim of this study is to determine the students-level and schoollevel factors that are related to reading ability achievement of students who participated PISA 2015 (Programme for International Student Assessment) from Turkey. The effects of the student and school level factors on reading achievement of students were tested by 2 level hierarchical linear model. According to the findings, there are differences between schools in terms of students' reading ability scores in Turkey. When the findings of the effects of the student level variables on the reading ability scores are examined; mother's socio-economic status, parental emotional support, and unfair teacher behavior variables seem to affect students' reading ability achievement. When the findings of the effects of the school level variables on the reading ability scores are examined; school size, teacher education level, and student behavior that hinders learning variables have a significant effect on the average reading ability scores of schools. When the student and school level variables mentioned above were modeled together, the significant effect of the school size variable was lost while the teacher education level and the student behavior that hinders learning variables continued to have a significant effect on the schools average reading ability scores.
\end{abstract}

\section{INTRODUCTION}

The evaluation of the quality of education is crucial. The most commons of these evaluation methods in recent years are the PISA and TIMMS exams which are also applied in Turkey. Thanks to these exams, countries can see their level of education in the world compared to other countries. The PISA (Programme for International Student Assessment) is a screening survey conducted by the Organization for Economic Co-operation and Development (OECD) every 3 years and assesses the knowledge and skills gained by 15-year-old students (OECD, 2000; Schleicher, 2007; Breakspear, 2012). PISA focuses on the ability of young people using their skills and knowledge to cope with real life challenges (Reinikainen, 2012). The assessment, which focuses on reading, mathematics, science and problem-solving, not only recognizes that students can repeat what they have learned, but also examines how well they are able to benefit what they have learned and how they can apply this knowledge in and out of the school 
environment. This approach reflects the fact that modern societies reward what the students can do instead of what they know (OECD, 2014).

In a short time, PISA has gone a long way and reinforced the role of OECD and its Education Directorate as a leading global organization to develop and analyze comparative international education performance data. PISA results now have a very high profile in the national media and are in the awareness of high-level politicians (Fairclough, 2000; Lingard \& Rawolle, 2004, Grek, 2009). As Gür, Çelik and Özoğlu (2012) stated countries shape their educational policies according to PISA results. PISA results enable policy makers from around the world to measure the knowledge and skills of their country's students compared to other countries, to set policy targets, and to learn from applied policies and practices elsewhere (Ringarp \& Rothland, 2010).

PISA assesses the application of knowledge in mathematics, reading and science literacy to problems in the context of real life (OECD, 1999). The PISA uses the term "literacy" in each area to show focus on the application of knowledge and skills. For example, when reading is assessed, PISA assesses how well students in the $15^{\text {th }}$ year understand, use and reflect the written text for various purposes and environments. In science, PISA assesses how students can apply scientific knowledge and skills to different situations they may encounter in their lives. Similarly, in mathematics, PISA evaluates how students analyze, reason, and interpret mathematical problems in various situations. The scores on the PISA scales represent skill levels throughout the continuity of literacy skills. PISA provides a range of proficiency levels associated with points that define what a student can typically do at each level (OECD, 2006).

Mathematics and science education constitute large and dynamic elements of schooling that are generally viewed as important to individual students in enhancing their understanding of the world and improving their chances of lifetime achievement and also important at the larger societal level in today's knowledge-based economy where the capacities of the citizenry are directly linked to the well-being of the nation. However, the importance of mathematics and science education is a distant second compared to the importance ascribed to language and literacy education, especially reading (Yore, Anderson \& Chiu, 2010). According to Wellington and Osborne (2001); to be successful in math and science, students should understand what they read. Therefore, in this study the factors that affect the reading literacy of pupils are investigated.

Apart from tests that assess students' knowledge in mathematics reading and science literacy, in PISA, some questionnaires are also applied. These questionnaires are designed to get information about students and their families' background including their economic, social and cultural capital, students' attitudes towards learning, the life aspects of students such as their habits in and out of the school and, their lives and families, the quality of human and material resources of schools, aspects of the school's such as teaching and learning processes, staffing practices and emphasis on curriculum and extracurricular activities, organizational structures and genres, class size, classroom and school environment and instructional content, including science activities in the classroom (Rindermann, 2007). In the current study the factors that affect the reading literacy achievement of students are determined according to the results of these questionnaires.

When the literature is examined, some research studies on the subject are available. Yildirim (2012) investigated the student and school variables that influence PISA 2009 reading comprehension skills, Willms (2001) investigated the differences in the level of reading comprehension in the Canadian provinces, and the factors that make this difference, Lietz and Kotte (2004) compared the factors that affect the achievement of Finland's, which is the most successful country in reading skills according to PISA 2000 results, and Germany's, which is under average, Linnakyla, Malin and Taube (2004) compared PISA 2000 reading ability scores of Finnish and Swedish students and tried to explain the reason of the difference, Kotte, Lietz 
and Lopez (2005) used PISA 2000 data to investigate the factors that encourage and impede students' reading achievement in Germany and Spain, Nonoyama (2006) investigated the factors that affect the school-based and family-based factors in achievement of students in reading skills. Besides these Thomson, Bortoli, Nicholas, Hillman and Buckley (2010) investigated PISA results for Australia, Wilmms (2001) and Catwright and Allen (2002) for Canada, Rindermann (2007) for Denmark, Brozo, Shiel and Topping (2007) for Ireland, Scotland and the U.S.A, Grek (2009) for England, Finland and Germany.

When the literature was investigated, no studies were conducted on PISA 2015 data. When we look at the work done in the past years, we have not encountered a study which deals specifically with the variables of our study. PISA results reveal what is possible in education by demonstrating what the highest performing and fastest growing educational system can do. While applying cognitive tests to students, at the same time PISA also applies student, parents and school questionnaires in order to evaluate the factors that affect students' achevement. In the student questionnaire, the student is asked questions about his / her home (family, computer use, technology use, etc.); In the school questionnaires, the school administrator or an authorized person is asked questions about the structure of the school, the resources of the school, the situation of students and teachers, educational policies and school climate. While the PISA project demonstrates the academic achievement of students on an international scale through cognitive tests, it also measures the relationship between school resources at national and international levels with the data obtained from school surveys; it also reveals similarities and differences between different schools. Findings allow policy makers around the world to measure the knowledge and skills of students in their countries compared to other countries, to set policy targets against measurable targets in other education systems, and to learn from applied policies and practices elsewhere (MEB, 2015). But according to Özdemir (2017), in Turkey the studies on PISA are mostly not original, these studies are repetition or the interpretation of the results published by MEB (Turkish Ministry of National Education) and OECD. Therefore, original studies in this field are needed. The hierarchical linear modeling approach is a two-level strategy (Hoffman, Griffin and Gavin, 2000) that investigates the variables involved in two-step analysis. As the PISA data are hierarchical, this approach is very convenient. Students who are the sample group of PISA are in classrooms, classes in schools, schools in cities, and cities in countries. In this context the aim of this study is to determine the personal and school-based factors that affect Turkish students' reading achievement in PISA 2015.

\section{METHOD}

\subsection{Study Group}

In PISA 2015, the 15 year-old student population was determined to be 925.366 students. In the PISA study, school sampling was determined by stratified random sampling method. At the first stage for PISA 2015 application, schools were selected by stratified random sampling method in the Classification of Statistical Region Units (NUTS) Level 1, type of education, type of school, place of schools and administrative forms of schools, and in the second stage students who were to participate in these schools were determined by random method . 5895 students from 187 schools in 61 cities that represent 12 regions participated in the exam (MEB, 2015). $20.7 \%$ of students participating in PISA 2015 application are 9th grade students and $72.9 \%$ are 10th grade students. $75 \%$ of the students attend vocational high schools and Anatolian high schools. $50 \%$ of the students are male and $50 \%$ of the students are female.

\subsection{Data Collection Tools}

The data on students' achievements in reading comprehension, mathematics and science, and demographic, socio-economic and educational variables that may be related to achievement in 
these areas were collected by PISA 2015 performance tests and questionnaires. In the research, these tests and questionnaires were used. These data for PISA 2015 was obtained from the official website of the OECD (http://www.oecd.org/pisa/data/2015database) which carried out PISA applications. The student and school level variables determined in the study are given in Table 1.

Table 1. Student and School Level Explanatory Variables

\begin{tabular}{ll}
\hline Student Level (1st Level) & School level (2nd Level \\
\hline Mother's Education Level & School Size \\
\hline Father's Education Level & Educational Leadership of School Director \\
\hline Mother's Socio Economic Status & Instructional Leadership of School Director \\
\hline Father's Socio Economic Status & Lack of Educational Equipment \\
\hline Class Repetition & Lack of Staff \\
\hline Study Time Out of School & Teacher Behavior That Hinders Learning \\
\hline Math Study Time & Student behavior That Hinders Learning \\
\hline Turkish Study Time & \\
\hline Science Study Time & \\
\hline Belonging to School & \\
\hline Co-operation Skills & \\
\hline Parental Emotional Support & \\
\hline Unfair Teacher Behavior & \\
\hline
\end{tabular}

\subsection{Data Analysis Procedure}

After the normality assumptions are tested by Kolmogorov-Smirnov test and met, a two-level HLM was conducted to determine the relation between PISA 2015 students' reading ability achievements and student and school characteristics. Data statistical programs and; a hierarchical linear model program was used. A minimum of .05 was taken as the basis for the statistical significance test.

In social sciences, data are generally nested hierarchically in structure. The best example of this situation is seen in educational sciences. The students are in the classes, the classes are in the schools, the schools are in the regions and the regions are in the countries. Therefore, when we do analyses, we can not consider the students separate from the classes or the schools they are in. Hierarchical linear models allow us to analyze these variables together (Raudenbush \& Bryk, 2002). In this study, a two-level hierarchical model was established by taking student variables as Level 1 and school variables as Level 2.

Four HLM models were used to reach the objectives of the study. These; The One-Way ANOVA with random effects model, the random coefficient regression model, the regression model in which the intercepts are outcomes, and the model in which intercepts and slopes are outcomes. A One-Way ANOVA with random effects model; is the simplest form of hierarchical linear models. It is also called an empty model (Hox, 2002). First, a One-Way ANOVA with random effects model is established and hierarchical linear models are started. The objective is to distinguish the dependent variable according to the different levels of the hierarchy. This model includes only random groups and variances within these groups. The One-Way ANOVA with random effects model is used to generate the point estimate and confidence interval for the 
large intercept. It also provides information on output variability in each of the two levels (Acar, 2013). In the random coefficient regression model, all of the submodels are treated with the assumption that the fixed parameter is a randomly changing model. There are no Level 2 independent variables in the model that explain the intercept and slope parameters. In the regression model in which the intercepts are outcomes, the predictions are made using the Level 2 variables. Regression model consists of group intercepts which are predicted by Level 2 variables. Within the scope of the research, Level 1 of this model was constructed as the first step of the random-effects ANOVA model. In Level 2, school-level variables, the effects of which are sought on students' reading achievement, are added to the model. The last model is the model in which intercepts and slopes are outcomes. It is also called as full model as it contains all the 1st and 2nd Level variables together (Raudenbush \& Byrk, 2002). In this model Level 1 variables are added and the change on the effect of Level 2 variables on the dependent variable is observed.

\section{RESULT / FINDINGS}

We presented the descriptive statistics for the first sub-problem of the study in Table 2. We established a One-Way ANOVA with random effects model in order to answer the research question: "Are there differences between schools in terms of the students' reading achievement?"

Table 2. Fixed Coefficients for One-Way ANOVA with Random Effects Model

\begin{tabular}{lccccc}
\hline Fixed Effects & Coefficients & Standard Error & $\mathrm{t}$ & $\mathrm{df}$ & $p$ \\
\hline Reading Skills & 458.861 & 5.728 & 80.105 & 110 & 0.000 \\
\hline
\end{tabular}

As depicted in Table 2, there is a significant difference in reading skills achievement among schools $(p<0.01)$. The average reading scores of schools are 458,861. We presented the random effect for one-way ANOVA with random effects model in table 3.

Table 3. Random Effects for One-Way ANOVA with Random Effects Model

\begin{tabular}{lcccc}
\hline Random Effect & Variance & $\mathrm{df}$ & $\chi^{2}$ & $p$ \\
\hline INTERCEPT & 2861.809 & 110 & 887.301 & .000 \\
\hline Level1 Effect & 2213.043 & & & \\
\hline
\end{tabular}

As seen in Table 3, the random effects are significant in school level ( $\chi 2=887.301$, df110, $p<0.01)$. This indicates that the difference between the schools in terms of the average reading comprehension scores is random. In addition, it was determined that the change in the intercept score of reading between schools was caused $56 \%$ by school variables and $44 \%$ by student variables $(2861 /(2861+2213))$. Reliability is calculated as 0.78 when the reliability of the Level 1 coefficients, which give information about whether the average obtained from the sample is a sign of the actual school average. This suggests that the average obtained from the sample is a reliable indicator of the true school average. In this respect, the model is established as follows.

Levell Model

$$
\operatorname{READINGij}=\beta 0 \mathrm{j}+\mathrm{rij}
$$

Level2 Model

$$
\beta 0 \mathrm{j}=\gamma 00+\mathrm{u} 0 \mathrm{j}
$$

Mixed Model 
READINGij $=\gamma 00+\mathrm{u} 0 \mathrm{j}+\mathrm{rij}$

READING $=$ It is the literacy intercept of the students attended PISA 2015 application from Turkey.

$\beta 0 \mathrm{j}=\mathrm{It}$ is the literacy intercept of the students for school.

$\mathrm{rij}=\mathrm{It}$ is the error of Level 1 equation.

$\gamma 00=\mathrm{It}$ is the intercept of schools number $\mathrm{j}$.

$\mathrm{u} 0 \mathrm{j}=\mathrm{It}$ is the random effect.

We established the random coefficient regression model in order to answer the second subproblem of the study "What are the student-level variables that have significant effects on students' reading comprehension achievements?". We initially included 13 variables to the model. These are; the educational status of the mother, the educational status of the father, the socio-economic level of the mother, the socio-economic level of the father, the grade repetition, the study time outside the school, the student behavior that prevents learning, mathematics study time, Turkish study time, science study time, feelings of belonging, enjoyment of cooperation, emotional support of the family, unfair teacher behavior. The significant ones among these variables are presented in Table 4.

Table 4. Fixed Coefficents for Random Coefficient Regression Model

\begin{tabular}{llllll}
\hline Fixed Effects & Coefficients & $\begin{array}{l}\text { Standard } \\
\text { Error }\end{array}$ & $\mathrm{t}$ & $\mathrm{df}$ & $p$ \\
\hline Intercept, $\beta 00$ & 456.077067 & 5.531659 & 82.449 & 118 & 0.000 \\
Mother's Socio-Economic Status, $\gamma 10$ & 0.504272 & 0.109915 & 4.588 & 374 & 0.000 \\
Parents Emotional Support, $\gamma 20$ & 5.715517 & 2.388353 & 2.393 & 374 & 0.017 \\
Unfair Teacher Behavior, $\gamma 30$ & -2.107095 & 0.614764 & -3.427 & 374 & 0.000 \\
\hline
\end{tabular}

When Table 4 is investigated, it is seen that the variables that affect students' reading ability achievement are mother's socio-economic status, parents' emotional support and unfair teacher behavior. According to Table 4, there is a significant positive correlation between the student's reading ability score and the mother's socio-economic status $(\beta 10=0.504, \mathrm{SE}=0.10, \mathrm{p}<0.05)$. When other variables are held constant, a unit increase in mother's socio-economic status increases reading skills by 0.504 units. There is a significant positive correlation between students' reading ability scores and family emotional support $(\beta 20=5.715, \mathrm{SE}=2.388, \mathrm{p}<0.05)$. Students who perceive the emotional support of the family are more successful in the field of reading skills than other students. There is a significant negative correlation between students' reading ability scores and unfair teacher behavior perception variables $(\beta 50=-2.107, \mathrm{SE}=0.61$, $\mathrm{p}<0.05$ ). It is seen that the more unfair teacher behaviors are, the less students' reading ability scores are. According to these data, we presented the model as;

Level 1 Model

$$
\text { READINGij }=\beta 0 j+\beta 1 j *(B S M J 1 i j)+\beta 2 j *(\text { PARSUPij })+\beta 3 j *(U N F A I R T E i j)+\text { rij }
$$

Level-2 Model

$$
\begin{aligned}
& \beta 0 \mathrm{j}=\gamma 00+\mathrm{u} 0 \mathrm{j} \\
& \beta 1 \mathrm{j}=\gamma 10 \\
& \beta 2 \mathrm{j}=\gamma 20 \\
& \beta 3 \mathrm{j}=\gamma 30
\end{aligned}
$$


$\beta 4 \mathrm{j}=\gamma 40$

Mixed Model

READINGij $=\gamma 00+\gamma 10 *$ BSMJ $1 i j+\gamma 20 *$ PARSUPij $+\gamma 30 *$ UNFAIRTEij $+\mathrm{u} 0 \mathrm{j}+\mathrm{rij}$

READING $=$ It is the literacy intercept of the students attended PISA 2015 application from Turkey.

BSMJ1 = It is mother's socio-economic status.

PARSUP $=$ It is parental emotional support.

UNFAIRTE $=$ It is unfair teacher behavior.

$\beta 0 \mathrm{j}=\mathrm{It}$ is the reading intercept of $\mathrm{j}$ school.

$\beta 1 \mathrm{j} \ldots . . . \beta 4 \mathrm{j}=$ Intercept differences between schools.

$\gamma 00=$ It is the expected value of constant parameters on Level 2 units.

$\gamma 10 \ldots \ldots \gamma 40=$ They are the expected value of slope parameters on Level 2 units.

$\mathrm{u} 0 \mathrm{j}=\mathrm{It}$ is Level $2 \mathrm{j}$ unit's change in constant parameter.

rij $=$ It is the error of Level 1 .

The regression model in which the intercepts are outcomes was established in order to answer the $3^{\text {rd }}$ sub-question of the study "What are the school level variables that that have significant effects on students' reading comprehension achievements?". Table 5 shows the fixed and random effects on the intercept reading score of the school according to the regression model in which the intercepts are outcomes of school variables.

Table 5. Fixed and Random Effects of the Regression Model in Which The İntercepts Are Outcomes of School Variables

\begin{tabular}{|c|c|c|c|c|c|c|c|}
\hline \multicolumn{2}{|l|}{ Fixed Effects } & & Coefficients & Standard Error & $\mathrm{t}$ & $\mathrm{df}$ & $p$ \\
\hline \multicolumn{2}{|l|}{ INTERCEPT, $\gamma 00$} & & 458.707530 & 4.880027 & 93.997 & 107 & 0.000 \\
\hline \multicolumn{2}{|c|}{ SCHOOLSIZE, $\gamma 01$} & & -0.024048 & 0.007177 & -3.351 & 107 & 0.001 \\
\hline \multicolumn{2}{|c|}{ TEACHER EDUCATON LEVEL, $\gamma 02$} & & 477.0057 & 179.673 & 2.655 & 107 & 0.009 \\
\hline \multicolumn{2}{|c|}{ STUDENT BEHAVIOR, $\gamma 03$} & & -22.774649 & 4.843012 & -4.703 & 115 & 0.000 \\
\hline Random Effect & Variance & df & $\chi^{2}$ & $p$ & & & \\
\hline INTERCEPT, r0 & 2008.94783 & 107 & 613.75481 & 0.000 & & & \\
\hline Level 1 Effect, e & 2208.15542 & & & & & & \\
\hline
\end{tabular}

As depicted in Table 5, the school level variables that affect students' reading ability achievement are school size, teachers' educational level, and student behavior that hinders learning. There is a negative correlation between students' reading ability scores and school size $(\beta 01=-0.024$, Standard Error $(\mathrm{SE})=0.007, \mathrm{p}<0.05)$. As the number of students increases, the scores of reading skills of the students decrease. There is a positive significant relationship between the reading ability scores of the students and the education levels of the teachers ( $\beta 02$ $=477.005, \mathrm{SE}=179.673, \mathrm{p}<0.05)$. As the level of education of teachers increases, the scores of students' reading skills also increase. There is a negative relationship between students' reading ability scores and student behaviors that prevent learning $(\beta 03=-22,774 \mathrm{SE}=4.84, p$ $<0.05$ ). The more students' behaviors that prevent students from learning is, the lower their reading ability scores are. According to these data the regression model in which the intercepts are outcomes is established as;

Level-1 Model

$\mathrm{READINGij}=\beta 0 \mathrm{j}+\mathrm{rij}$ 
Level-2 Model

$$
\beta 0 \mathrm{j}=\gamma 00+\gamma 01 *(\mathrm{SCHSIZEj})+\gamma 02 *(\mathrm{TEACEDLEV} \mathrm{j})+\gamma 03 *(\mathrm{TEACBEHj})+\mathrm{u} 0 \mathrm{j}
$$

Mixed Model rij

READINGij $=\gamma 00+\gamma 01 * *(\operatorname{SCHSIZEj})+\gamma 02 *($ TEACEDLEVj $)+\gamma 03 *(\mathrm{TEACBEHj})+\mathrm{u} 0 \mathrm{j}+$

SCHSIZE $=$ It is the school size.

TEACEDLEV = It is the teachers' education level.

$\mathrm{TEACBEH}=\mathrm{It}$ is the teacher behavior that hinders learning.

$\beta 0 \mathrm{j}=\mathrm{It}$ is the reading achievement of school $\mathrm{j}$.

$\beta 1 \mathrm{j} \ldots . . . \beta 4 \mathrm{j}=$ Intercept differences between schools.

$\gamma 00=\mathrm{It}$ is the expected value of constant parameters on Level 2 units.

$\gamma 01 \ldots . . \gamma 03=$ They are the differentiating effects of school level variables on school average achievement.

$\gamma 10 \ldots \ldots \gamma 40=$ They are the expected value of slope parameters on Level 2 units.

$\mathrm{u} 0 \mathrm{j}=\mathrm{It}$ is Level $2 \mathrm{j}$ unit's change in constant parameter.

rij $=$ It is the error of Level 1 .

We established the model in which intercepts and slopes are outcomes to answer the 4th subquestion of the study "When the student-level variables that affect reading ability achievement of the students significantly are added in the model, how do school level variables affect reading ability achievement of the students?". In Table 5 we presented the results of the model in which intercepts and slopes are outcomes.

Table 6. Fixed and Random Effects of the Model in Which Intercepts and Slopes Are Outcomes

\begin{tabular}{|c|c|c|c|c|c|}
\hline Fixed Effects & Coefficients & $\begin{array}{l}\text { Standard } \\
\text { Error }\end{array}$ & $\mathrm{t}$ & df & $p$ \\
\hline Intercept, $\gamma 00$ & 443.436647 & 6.627748 & 66.906 & 107 & $<0.001$ \\
\hline SCHOOLSIZE, $\gamma 01$ & -0.002900 & 0.011157 & -0.260 & 107 & 0.795 \\
\hline \multicolumn{5}{|l|}{ TEACHER EDUCATION } & 0.013 \\
\hline STUDENT BEHAVIOR, $\gamma 0$ & -19.945674 & 4.590593 & -4.345 & 107 & $<0.001$ \\
\hline \multicolumn{6}{|c|}{ MOTHER'S SOCIO-ECONOMIC STATUS, $\beta 1$} \\
\hline Constant, $\gamma 10$ & 0.358402 & 0.102493 & 3.497 & 371 & $<0.001$ \\
\hline School Size, $\gamma 11$ & -0.000528 & 0.000186 & -2.840 & 371 & 0.005 \\
\hline Constant, $\gamma 20$ & 5.428292 & 2.251499 & 2.411 & 371 & 0.016 \\
\hline \multicolumn{6}{|c|}{ UNFAIR TEACHER BEHAVIOR, $\beta 3$} \\
\hline Constant, $\gamma 30$ & -1.579701 & 0.520183 & -3.037 & 371 & 0.003 \\
\hline School Size, $\gamma 31$ & 0.002506 & 0.001194 & 2.099 & 371 & 0.037 \\
\hline Random Effect & Variance & $\chi^{2}$ & $\mathrm{p}$ & & \\
\hline Intercept, r0 & $2034.02824 \quad 115$ & 710.76624 & 0.000 & & \\
\hline Level1 Effect, e & 1980.39148 & & & & \\
\hline
\end{tabular}

When Table 6 is investigated it can be seen that the student level variables are added in the model the significant effect of school level variables on students' reading ability achievement that were presented in the regression model in which the intercepts are outcomes, except for 
school size, continues $(\mathrm{p}<0,05)$. However, the significant effect of the school size variable was lost when the student-level variables included in the model. However, when the school size variable is combined with the unfair teacher behavior variable, it has a significant effect. When the school size variable model is combined, the negative effect of students' perception of unfair teacher behavior decreases to some extent. Again, the school size becomes significant when it is combined with the socio-economic status of mother variable. In large schools, the effect of socio-economic status of the mother is less. In this respect, the model in which intercepts and slopes are outcomes is;

Level-1 Model

READINGij $=\beta 0 \mathrm{j}+\beta 1 \mathrm{j} *($ BSMJ1ij $)+\beta 2 \mathrm{j} *($ PARSUPij $)+\beta 3 \mathrm{j} *($ UNFAIRTEij $)+$ rij

Level-2 Model

$\beta 0 \mathrm{j}=\gamma 00+\gamma 01 *(\mathrm{SCHSIZEj})+\gamma 02 *(\mathrm{TEACEDLEVj})+\gamma 03 *(\mathrm{TEACBEHj})+\mathrm{u} 0 \mathrm{j}$

$\beta 1 \mathrm{j}=\gamma 10+\gamma 11 *($ SCHSIZEj $)$

$\beta 2 \mathrm{j}=\gamma 20$

$\beta 3 \mathrm{j}=\gamma 30+\gamma 31 *($ SCHSIZEj $)$

Mixed Model

READINGij $=\gamma 00+\gamma 01 *$ SCHSIZEj $+\gamma 02 *$ TEACEDLEVj $+\gamma 03 *$ TEACBEHj $\quad+\gamma 10 *$ BSMJ1ij $+\gamma 11 *$ SCHSIZEj * BSMJ1ij $+\gamma 20 *$ PARSUPij $+\gamma 30 *$ UNFAIRTEij $+\gamma 31$ SCHSIZEj * UNFAIRTEij + u0j+ rij

SCHSIZE $=$ It is the school size.

TEACEDLEV $=$ It is the teachers' education level.

TEACBEH $=$ It is the teacher behavior that hinders learning.

BSMJ1 = It is mother's socio-economic status.

PARSUP $=$ It is parents emotional support.

UNFAIRTE $=$ It is unfair teacher behavior.

$\beta 0 \mathrm{j}=\mathrm{It}$ is the reading intercept of $\mathrm{j}$ school.

$\beta 1 \mathrm{j} \ldots . . . \beta 4 \mathrm{j}=$ Intercept differences between schools.

$\gamma 00=$ It is the expected value of constant parameters on Level 2 units.

$\gamma 01 \ldots . . \gamma 03=$ They are the differentiating effects of school level variables on school average achievement.

$\gamma 10 \ldots \ldots \gamma 40=$ They are the expected value of slope parameters on Level 2 units.

$\mathrm{u} 0 \mathrm{j}=\mathrm{It}$ is Level $2 \mathrm{j}$ unit's change in constant parameter.

rij $=$ It is the error of Level 1.

\section{DISCUSSION and CONCLUSION}

Our study states that there is a significant difference between schools in terms of reading ability achievement of students in Turkey. This is consistent with many studies. Thomson et.al. (2010) examined PISA 2009 reading skills outcomes for Australia and found that there were significant differences between Australian schools in reading skills. Similar studies were conducted by, Rindermann (2007) for Denmark, Brozo, Shiel and Topping (2007) for Ireland, Scotland and the USA, Grek (2009) for England, Finland and Germany and Yıldırım (2012) for Turkey. In all of these studies, the PISA reading ability scores showed significant differences between schools. As the studies were conducted in different years and in different countries, it can be said that there are differences in reading skills across the world in all years.

In our study, we investigated the factors that cause the differences between schools and we found out that the student level variables are; socio-economic status of the mother, emotional 
support of the family, and perception of the teacher's unfair teacher behavior. Acar (2013) investigated the results of 2005 and 2008 Turkey Student Achievement Test (SAT) and found the student-level factors that affect reading ability achievement of students as; gender of the student, father's education level, the number of books the student has, the time for reading, the belief of success in Turkish class and the state of taking private lessons from Turkish. In her study, in which she investigated the PISA 2009 reading ability achievements of students, Y1ldirım (2012) revealed that the factors that affect students' success are; gender, enjoyment of reading, parents' socio-economic status and number of the books the student has.

As a result of the research, it was revealed that the socio-economic status of the mother affects the reading ability score positively. This result is consistent with the studies made by Anilan (1998), Ates (2008), Bölükbaşı (2010), Kaldan (2007), Öztürk (2010) and Kahraman and Çelik (2017). As the socio-economic status and educational level of the parents increase, students' reading achievement increases. Moreover, this is not only the case for reading achievement, but also for other courses. For example, Erberber (2010) found that parents' socio-economic status was influential on the mathematical achievement of students in TIMSS. According to our study another variable that affects reading achievement of students is parents' emotional support. Christenson, Rounds and Gorney (1992), Desimone (1999), Swap (1993), Gümüşeli (2004) and Çelenk (2003) put forward that family support is a prerequisite for success. From this point of view, we suggest that organizing seminars for parents to increase their support for their children may be helpful to increase students' success.

Another result of our study is that there is not a significant correlation between study time out of school and having private Turkish lessons and students' reading achievement. In the study that they investigated the effect of homework on students' achievement, Kapikiran and Kiran (1999) concluded that students who get less homework are more successful than students who get more homework. However; Grodner and Rupp (2013) concluded that homework had positive effects on the learning of students. Considering this data, it can be said that the quality of the homework given to the students is important and sufficient homework should be given so that students can do reinforcement instead of giving too much homework.

We found out that unfair teacher behaviour perceptions of students affect students' reading achievement in a negative way. Fryer (2013), Allen, Gregory, Mikami, Lun, J., Hamre and Pianta (2013) and Jones and Jones (2015) found significant relationships between teacher behavior and student achievement. As the positive teacher behaviors increase, the success and attitudes of the students are found to be positive. For this reason, it can be said that the positive attitude and behavior of the teachers towards the students will increase the success.

As a result of the research, school variables that affect students' reading achievement were school size, teachers' education level and student behavior that hinders learning. There is a negative relationship between school size and the success of reading skills. Fredriksson, Öckert and Oosterbeek (2013) and Leithwood and Jantzi (2009) found negative relationships between school size and success. Therefore, smaller schools instead of larger ones may increase the success.

According to the results of the research, there is a positive relation between the education level of the teachers in the schools and the reading ability scores of the students. As the education levels of teacher's increase, the success of students' reading skills also increases. In this data, teachers should be encouraged to constantly improve themselves and to continue their master education.

In this study the data from Turkey were used. Other countries can be included in the study and comparative statistics can be made. Results related to reading skills in Turkey was investigated. The results of science and mathematics achievement may also be investigated. Two levels of HLM was done in the study by taking the students and school levels into consideration. Levels 
such as class and district levels can be added and three or four level models can be established. The research was conducted for PISA exam results. Similar examinations can be made in examinations like TIMMS and the results of the research can be compared.

\section{Acknowledgements}

This study was derived from the PhD thesis supported by Pamukkale University Scientific Research Projects Coordination Unit with project number 2018EĞBE009.

\section{Declaration of Conflicting Interests and Ethics}

The authors declare no conflict of interest. This research study complies with research publishing ethics. The scientific and legal responsibility for manuscripts published in IJATE belongs to the author(s).

\section{ORCID}

\section{Kazım ÇELIK (D) https://orcid.org/0000-0001-7319-6567}

Ahmet YURDAKUL (D) https://orcid.org/0000-0002-9995-7157

\section{REFERENCES}

Allen, J., Gregory, A., Mikami, A., Lun, J., Hamre, B., \& Pianta, R. (2013). Observations of effective teacher-student interactions in secondary school classrooms: Predicting student achievement with the classroom assessment scoring system-secondary. School Psychology Review, 42(1), 76.

Anılan, H. (1998). Beşinci sınıf ögrencilerinin Türkçe dersinde okuduğunu anlama becerisiyle ilgili hedef davranışların gerçekleşme düzeyleri [Level of achievement of the general objectives related to the ability of understanding reading in Turkish leassons by fifth grade students]. Unpublished Master Dissertation, Pamukkale Üniversitesi, Denizli.

Akyol, H., Ateş, S., \& Yıldırım, K. (2008). Sınıf öğretmenlerinin kullandıkları okuma stratejileri ve bu stratejileri tercih nedenleri [Reading strategies used by primary school teachers and the reasons for choosing these strategies]. VII. National Symposium on Teacher Education (2-4 May 2008). Çanakkale. Çanakkale Onsekiz Mart Üniversitesi. Ankara: Nobel Yayın Dağıtım, 723-728.

Bölükbaşı, C., \& Sarıbaş, M. (2011). İlköğretim Birinci Kademe (1, 2, 3. Sınıf) Türkçe Öğretimi Sorunlar1. [Primary Education (1st, 2nd, 3rd Grade) Turkish Teaching Problems]. Academic student journal of Turkish researches, (1), 20-26.

Breakspear, S. (2012). The policy impact of PISA: An exploration of the normative effects of international benchmarking in school system performance. OECD Education Working Papers, (71), 1.

Brozo, W. G., Shiel, G., \& Topping, K. (2007). Engagement in reading: Lessons learned from three PISA countries. Journal of Adolescent \& Adult Literacy, 51(4), 304-315.

Cartwright, F., \& Allen, M. K. (2002). Understanding the rural-urban reading gap. Human Resources Development Canada. Service Canada, Ottawa, ON K1A 0J9, Canada.

Christenson, S. L., Rounds, T., \& Gorney, D. (1992). Family factors and student achievement: An avenue to increase students' success. School Psychology Quarterly, 7(3), 178.

Çelenk, S. (2003). Okul başarısının ön koşulu: Okul aile dayanışması [The Prerequisite for School Success: Home-School Cooperation]. Illköğretim online, 2(2).

Desimone, L. (1999). Linking parent involvement with student achievement: Do race and income matter? The journal of educational research, 93(1), 11-30.

Erberber, E. (2010). Analyzing Turkey's data from TIMSS 2007 to investigate regional disparities in eighth grade science achievement. In the Impact of International Achievement Studies on National Education Policymaking (pp. 119-142). Emerald Group Publishing Limited. 
Fairclough, N. (2000). New Labour, New Language? (London, Routledge).

Fredriksson, P., Öckert, B., \& Oosterbeek, H. (2013). Long-term effects of class size. Quarterly Journal of Economics, 128(1), 249-285.

Fryer, R. G. (2013). Teacher incentives and student achievement: Evidence from New York City public schools. Journal of Labor Economics, 31(2), 373-407.

Grek, S. (2009). Governing by numbers: The PISA 'effect'in Europe. Journal of education policy, 24(1), 23-37.

Grodner, A., \& Rupp, N. G. (2013). The role of homework in student learning outcomes: Evidence from a field experiment. The Journal of Economic Education, 44(2), 93-109.

Gümüşeli, A. İ. (2004). Ailenin katılım ve desteğinin öğrenci başarısına etkisi. [The Family Factor on the Student's Success of School]. Özel okullar birliği bülteni, 2(6), 14-17.

Gür, B. S., Celik, Z., \& Özoğlu, M. (2012). Policy options for Turkey: A critique of the interpretation and utilization of PISA results in Turkey. Journal of Education Policy, 27(1), 1-21.

Güvendir, M. A. (2014). Öğrenci başarılarının belirlenmesi sınavında öğrenci ve okul özelliklerinin Türkçe başarısı ile ilişkisi [Student and School Characteristics' Relation to Turkish Achievement in Student Achievement Determination Exam]. Eğitim ve Bilim, Education and Science, 39(172), 20-26.

Hofmann, D. A., Griffin, M., A., \& Gavin, M. B. (2000). The application of hierarchical linear modeling to organizational research. In K. J. Klein \& S. W. J. Kozlowski (Eds.), Multilevel theory, research, and methods in organizations (pp. 467-511).

Hox, J. (2002). Quantitative methodology series. Multilevel analysis techniques and applications. Mahwah, NJ, US: Lawrence Erlbaum Associates Publishers.

Kahraman, Ü., \& Çelik, K. (2017). Analysis of PISA 2012 results in terms of some variables. Journal of Human Sciences, 14(4), 4797-4808.

Kaldan, E. S. (2007). İlköğretim 3. Sinıf Öğrencilerinin Türkçe Dersinde Okuduğunu Anlama Becerilerini Etkileyen Ekonomik ve Demografik Faktörler [Economic and demografic factors that affect the 3rd grade primary school students'reading comprehension skill in Turkish class]. Unpublished Master thesis, Gaziantep Üniversitesi.

Kapıkıran, Ş., \& Kıran, H. (1999). Ev ödevinin öğrencinin akademik başarısına etkisi. [The effect of homework on student's academic achievement]. Pamukkale University Faculty of Education Journal, 5(5), 54-60.

Kotte, D., Lietz, P., \& Lopez, M. M. (2005). Factors Influencing Reading Achievement in Germany and Spain: Evidence from PISA 2000. International Education Journal, 6(1), 113-124.

Leithwood, K., \& Jantzi, D. (2009). A review of empirical evidence about school size effects: A policy perspective. Review of educational research, 79(1), 464-490.

Lietz, P., \& Kotte, D. (2004). Factors influencing reading achievement in Germany and Finland: Evidence from PISA 2000. The Seeker, 215-228.

Lingard, B. \& Rawolle, S. (2004) Mediatizing educational policy: the journalistic field, science policy, and cross-field effects, Journal of Education Policy, 19(3), 361-380.

Linnakyla, P., Malin, A., \& Taube, K. (2004). Factors behind low reading literacy achievement. Scandinavian Journal of Educational Research, 48(3), 231-249.

Nonoyama, Y. (2006). A cross-national, multi-level study of family background and school resource effects on student achievement. Unpublished doctoral dissertation. Columbia University. Retrieved 6 July, 2007 from UMI.

Organization for Economic Cooperation and Development (OECD). (1999). Measuring Student Knowledge and Skills: A New Framework for Assessment. Paris: Author.

OECD. (2000). Measuring student knowledge and skills: The PISA 2000 assessment of reading, mathematics and science literacy. Paris: OECD 
OECD, P. (2014). Results: What Students Know and Can Do Student Performance in Mathematics, Reading and Science (Volume I, Revised edition, February 2014).

Organization for Economic Cooperation and Development (OECD). (2006). Assessing Scientific, Reading and Mathematical Literacy: A Framework for PISA 2006. Paris:

Özdemir, C. (2017). OECD PISA Türkiye Verisi Kullanılarak Yapılan Araştırmaların Metodolojik Taraması. [A Methodological Review of Research Using OECD PISA Turkey Data] Eğitim Bilim Toplum, 14(56), 10-27.

Öztürk, P. (2010). İlköğretim II. kademe Türkçe dersi performans görevi başarı puanları ile akademik başarl ve derse yönelik tutum arasındaki ilişkinin değerlendirilmesi [The evaluation of relation between success grades of Turkish lesson performance task and academic success and attitude to lesson in primary education school level]. Unpublished Master thesis, Karadeniz Teknik Üniversitesi, Trabzon.

Raudenbush, S. W., \& Bryk, A. S. (2002). Hierarchical linear models: Applications and data analysis methods (Vol. 1). Sage Publishing.

Reinikainen, P. (2012). Amazing PISA results in Finnish comprehensive schools. In Miracle of education (pp. 3-18). Sense Publishers.

Rindermann, H. (2007). The g-factor of international cognitive ability comparisons: The homogeneity of results in PISA, TIMSS, PIRLS and IQ-tests across nations. European Journal of Personality, 21(5), 667-706.

Ringarp, J., \& Rothland, M. (2010). Is the grass always greener? The effect of the PISA results on education debates in Sweden and Germany. European Educational Research Journal, 9(3), 422-430.

Schleicher, A. (2007). Can competencies assessed by PISA be considered the fundamental school knowledge 15-year-olds should possess? Journal of Educational Change, 8(4), 349-357.

Swap, S. M. (1993). Developing Home-School Partnerships: From Concepts to Practice. Teachers' College Press, Columbia University, 1234 Amsterdam Avenue, New York, NY 10027 (cloth--ISBN-0-8077-3231-1).

Taş, U. E., Arıcı, Ö., Ozarkan, H. B., \& Özgürlük, B. (2016). PISA 2015 Ulusal Raporu. [PISA 2015 National Report]. Ankara: Milli Ĕ̈itim Bakanlı̆̆l.

Thomson, S., De Bortoli, L., Nicholas, M., Hillman, K., \& Buckley, S. (2010). PISA in brief: highlights from the full Australian report: challenges for Australian education: results from PISA 2009: the PISA 2009 assessment of students' reading, mathematical and scientific literacy.

Wellington, J., \& Osborne, J. (2001). Language and literacy in science education. McGrawHill Education (UK).

Yıldırım, K. (2012). The main factors determining the quality of education in Turkey according to the PISA 2006 data. The Journal of Turkish Educational Sciences, 10(2), 229-255.

Yore, L. D., Anderson, J. O., \& Chiu, M. H. (2010). Moving PISA results into the policy arena: Perspectives on knowledge transfer for future considerations and preparations. Internati onal Journal of Science and Mathematics Education, 8(3), 593-609. 